\title{
Juridical Review of The Policy of a National Private Bank Towards the Restructuring of Credit Financing And Or Providing Additional Credits Or Capital Financing In The Covid-19 Pandemic Period
}

\author{
Roswita Sitompul ${ }^{1}$, Sulimin $^{2}$, Willy Tanjaya ${ }^{3}$, O.K. Isnainul ${ }^{4}$, Elvira Fitriyani Pakpahan ${ }^{5}$ \\ Universitas Prima Indonesia ${ }^{12345}$ \\ \{sulimin7277@yahoo.co.id², willytanjaya@unprimdn.ac.id ${ }^{3}$, \\ elvirapakpahan@unprimdn.ac.id $\left.{ }^{5}\right\}$
}

\begin{abstract}
Fulfillment of debtor obligations in the loan agreement during the Covid-19 pandemic, in general, there were several debtors who did not meet the achievements as in the credit agreement between the bank and the debtor. The policy of restructuring credit / financing and / or providing additional credit and capital financing for people's credit banks during the Covid 19 pandemic is a rescue action, while the options for action taken are Rescheduling, Reconditioning, Restructuring, Combination of reconditioning with restructuring, namely changing requirements and credit term with the addition of bank funds. Non-performing loans require immediate prevention and handling efforts by the bank so that non-performing loans are not sustainable into non-performing loans. Therefore, if bad credit continues without any efforts to prevent and treat it, it can affect the soundness of the bank which can cause the bank to go bankrupt. Therefore, there must be a settlement through legal channels in the case of non-performing loans and this is what the author will discuss. All forms of policy in the form of credit or financing restructuring and providing additional credit and capital financing for rural credit banks were carried out during the pandemic period, which is an effort by the banking bank to help smooth the circulation of money during the current pandemic. How do you fulfill the debtor's obligations in the loan agreement during the Covid-19 pandemic? What is the policy for restructuring credit / financing and / or providing additional credit or capital financing for rural banks during the Covid 19 pandemic? The approach method used in this research is a sociological juridical approach. The juridical approach is used to analyze various laws and regulations governing credit or financing restructuring policies and or providing additional credit or capital financing for rural banks during the pandemic. The existence of a credit relationship begins with an agreement between the borrower (debtor) and the lender (creditor and bank) as outlined in the form of an agreement. Credit in general can be given to anyone who has the ability to do so, namely by means of a debt agreement. If the agreement has been agreed upon, there will be an obligation on the creditor, namely, to deliver the agreed funds or money to the debtor with the right to receive the money back from the debtor at a predetermined time accompanied by the interest agreed by the parties at the time of the credit agreement. agreed and signed by both parties. Fulfillment of debtor obligations in the loan agreement during the Covid-19 pandemic, in general, there were several debtors who did not meet the achievements as in the credit agreement between the bank and the debtor.
\end{abstract}

Keywords: Credit Agreement; Bank; Creditors; the Covid-19 Pandemic 


\section{Introduction}

Banking institutions are financial institutions that have strategic value in the economic life of a country. This institution is intended to act as an intermediary between parties who have excess funds with parties who are deficient and need funds. Therefore, banks will be engaged in lending activities and various services provided, and banks will also serve financing needs and streamline payment system mechanisms for all sectors of the economy. Bank financial institutions have an important role, both in terms of carrying out their duties, to collect funds from the public in the form of savings and distribute them to the public in the form of credit and / or in other forms in order to improve the standard of living of the people at large.

Funds received by the public, whether in the form of deposits in the form of savings, current accounts and time deposits, are eventually circulated again by banks, for example through the money market, deposits, deposits in other forms and especially in the form of credit extension. The bank as a financial institution, in carrying out its role, aims to provide credit and other financial services. As an institution that runs a business in the financial services sector, banks are not just any business entity, but legally have a strong status with their own wealth capable of serving community needs, because it is trusted by the community.

The operational activities of the bank, both in an effort to raise funds from the public and manage funds, reinvest these funds into the community, until the funds are returned to the bank, always in accordance with legal provisions. Therefore, in line with the increasing and development of banking business activities, the role of the legal sector in supporting the success of these activities is increasingly felt to be important.

Economic development and the need for capital to do business because people's need for capital to tend to increase. In order to fulfill the people's, need for capital, the bank develops various forms of credit to help support the provision of capital. Credit is the most essential part of bank work. In addition to seeking profit and maintaining growth, the bank aims to serve its customers by providing credit and services in the payment traffic and circulation of the money. Provision of money or claims equivalent to this can be broadly defined, namely products of banking services, as long as they require provision of money or an equivalent bill, then it becomes a credit product.

Based on the definition of credit, the elements of credit can be identified, namely:

1. Trust, which is a belief in giving credit that the performance (money, services and goods) it gives will actually be received back in a certain future.

2. Time, that between the awarding of achievements and the taking is limited by a certain period of time. In this time element, there is the notion of money that money is now more valuable than money in the future.

3. Degree of risk, namely the provision of credit raises a level of risk, during the grace period is an abstract period. The risk arises for giving because money / goods in the form of achievements have been released to other people.

4. Achievement is an achievement in the form of goods, services and money. In this credit development, what is meant by the provision of credit is money.

In channeling credit or financing, the parties do so in the form of an agreement, which is known as a credit agreement or financing agreement. In this agreement, the bank as creditor and customer has their respective rights and obligations. The bank as the provider or credit provider / financing provider to provide money and the debtor is also obliged to return the credit according to the mutually agreed period of time. 
Banks as creditors (creditors) carry out their role based on a policy to always maintain the right balance between the desire to earn profits in the form of interest rates with the aim of liquidity, and bank solvency. What is meant by liquidity here is the bank's ability to guarantee the repayment of its short-term debts. Meanwhile, what is meant by solvency is the ability to pay off all debts (both short and long term). Where the bank's solvency also depends on the solvency of each customer. To maintain bank solvency, banks must be careful with potential borrowers so that certain requirements are required in the banking sector.

Non-performing loans require immediate prevention and handling efforts by the bank so that non-performing loans are not sustainable into non-performing loans. Therefore, if bad credit continues without any efforts to prevent and treat it, it can affect the soundness of the bank which can cause the bank to go bankrupt. Therefore, there must be solutions through legal channels in the case of non-performing loans and this is what the author will discuss. All forms of policies in the form of credit / financing restructuring and providing additional credit / capital financing for rural credit banks were carried out during the pandemic, which is an effort by the peripheral banks to help smooth the circulation of money during the current pandemic.

The bank's business to provide credit is intended as one of the bank's efforts to make a profit, so banks are only allowed to pass on public savings to their customers in the form of credit, one of which aims to save the debtor's business, if the bank truly believes that the debtor will return the loan received in accordance with the timeframe and the terms agreed by both parties. This shows the need to pay attention to the factors of ability and willingness, so that prudence can be drawn by supporting elements of security as well as elements of a credit.

From the above background, the writer is interested in making a scientific paper (thesis), while the title is a Juridical Review of Credit / Financing Restructuring Policies and / or Providing Additional Credit / Capital Financing for Rural Banks during the Covid-19 Period. Based on the description on the background, the problem formulations of this study are:

1. How is the credit agreement between the bank and the debtor?

2. What are the causes of the Non-Fulfillment of Debtor's Obligations in the Credit Agreement during the Covid-19 epidemic?

3. How are the Bank's Policies in Rescue of Non-Performing Loans during the Covid-19 epidemic?

Lending in general can be given to anyone who has the ability to do so, namely by means of a debt-receivable agreement. If the agreement has been agreed, there will be an obligation on the creditor, namely, to deliver the funds or money that has been agreed upon to the debtor with the right to receive the money back from the debtor at a predetermined time accompanied by the interest agreed by the parties at the time of the credit agreement. agreed and signed by both parties.

The Banking Law does not explicitly state what the legal basis for the credit agreement is. However, from the definition of credit, it is concluded that the legal basis for a credit agreement is lending and borrowing based on an agreement between the bank and the customer. In Article 1754 of the Criminal Code, it is stated that: Borrowing and lending is an agreement whereby one party gives the other party a certain amount of goods which are used up due to use, on the condition that the latter party will return the same amount of the same kind and condition. also.

Every credit that has been agreed upon by the credit provider (creditor) and the credit recipient (debtor) must be stated in the form of an agreement, namely a credit agreement. The agreement itself is regulated in Article 1313 of the Criminal Code. The credit agreement is rooted in the loan and loan agreement as regulated in Article 1754 of the Criminal Code. In making a credit agreement, it must also be seen and understood about the legal terms of the 
agreement stipulated in Article 1320 of the Criminal Code, namely the parties have agreed to make an agreement, the parties are capable of making an agreement, there are certain things that are agreed upon, and a lawful cause.

An agreement is an event where someone promises to someone else or where the two people promise each other to do something. In this incident there arises a legal relationship between the two people which is called an engagement. The agreement issues an agreement between the two people who make it. In its form, the agreement is in the form of a series of commitments containing pronounced or written promises or commitments.

\section{What are the causes of the Non-Fulfillment of Debtor's Obligations in the Credit Agreement during the Covid-19 epidemic?}

The reason why a debtor does not fulfill the obligations as agreed upon can be caused by two things, namely:

1. There is an error in the debtor

In this situation the debtor does not carry out his obligations not due to things that are beyond his control, so that the debtor who is not paying is said to be in default (default). It is different with an agreement where the achievement is not to do something, for example, to not build a wall that is more than two meters high, so once the debtor has built a wall that is more than two meters high since then it is in default. Regarding this, R Subekti said that now it is customary to interpret a warning for or a verbal warning, as long as it is sufficiently firm to state the debtor's urge to make an immediate achievement. So clearly what is meant by sommatie is a creditor's notification or statement to the debtor that contains the provisions that the creditor wants immediate achievement or within the period specified in the notification must be invoiced first.

Therefore, sommatie functions as a legal measure to determine the time when defaults occur. As a legal remedy, sommatie is only needed in the event that a creditor is going to demand compensation or in the event that a creditor asks for a termination of the engagement, sommatie is not needed, namely in the following cases: The debtor's condition is completely unable to fulfill his performance; The debtor admits the mistake; The circumstances are determined by law.

2. There is a state of force (overmacht / foree majeur)

Overmacht or force majeur is a condition that can cause a debtor to be unable to fulfill his / her performance to the creditor, where the situation arises beyond the control of the debtor and the situation that arises is also a condition that cannot be known at the time the agreement was made. The situation of overmacht / force majeure results in the following matters: The creditor is unable to request achievement from the debtor; The debtor cannot be declared negligent and therefore the debtor cannot be sued to compensate for losses; The risk does not pass to the debtor.

The Criminal Code does not publish the formulation referred to as overmacht / force majeur, Articles 1244, 1245, 1444 only explain that if a person is unable to fulfill an engagement or commits a legal violation due to coercive circumstances, then accountability cannot be held. Although the definition of force majeur is not formulated in the article of law, but by using the meaning contained in the articles of the Criminal Code which regulates force majeure, it can be concluded that an overmacht or force majeur is a situation in such a way because of the 
circumstances in which a forced engagement cannot. fulfilled and legal regulations have to be disregarded accordingly.

For a credit release by a bank to its customer, according to the procedure, it will always begin with a credit application by the customer concerned. If the bank deems the application appropriate to be granted, then in order to carry out the release of the credit, it must first be concluded with an agreement or agreement in the form of a credit agreement or debt acknowledgment. This is regulated in the Banking Law in Article 1 point 12, which states that credit is given based on a loan agreement between a bank and another party.

Credit agreements have important functions, both for creditors and for debtors, including:

1. Functioning as a principal agreement, namely the credit agreement is something that

determines the cancellation or non-cancellation of other agreements that follow, for example a guarantee binding agreement.

2. Serves as evidence regarding the boundaries of rights between creditors and debtors.

3. Serves as a tool for credit monitoring.

Basically, a bank credit agreement must meet 6 (six) minimum requirements, namely the amount of credit, the amount of interest, the time for repayment, the method of payment, clauses that contain matters regarding the loss of authority to act or the debtor's right to manage his assets, as well as goods. guarantee. Lending by a bank must be stated in a written credit agreement, either with a deed under hand or a notarial deed. The credit agreement serves as a bank guide in planning, implementing, organizing, and supervising the provision of credit carried out by the bank, so that the bank is not harmed and the interests of customers who entrust their funds to the best are guaranteed. Therefore, before giving credit, the bank must ensure that all juridical aspects related to credit are completed and have provided adequate protection for the bank.

The credit agreement is a standard agreement, where the contents or clauses of the credit agreement have been standardized and set forth in a form (blank), but are not bound in any particular form. Prospective debtor customers only need to put their signature if they are willing to accept the contents of the agreement, not giving the prospective debtor the opportunity to further discuss the contents or clauses submitted by the bank. This new agreement is needed to meet the needs of a practical and collective nature. At this stage, the position of the prospective debtor is very weak, so just accept the conditions offered by the bank, because otherwise the prospective debtor will not get the credit in question.

The credit agreement can end, namely the provisions of Article 1381 of the Criminal Code concerning the abolition of the engagement, the credit agreement is also subject to the law of the agreement. In practice, the credit agreement ends with the repayment of all debtor debts along with fines and other claims according to the agreement between the debtor and the bank. Thus, the credit agreement plays an important role in providing credit by the bank, namely as evidence of an agreement between the bank as a creditor and the debtor.

In providing credit, banks are required to have confidence in the ability and ability of the debtor to pay off their debts as agreed. To obtain this assurance, before extending credit, banks must carefully assess the character, ability, collateral capital and business prospects of the debtor. The factors that are assessed are known in banking with the $5 \mathrm{C}$ principle (the five of credit analysis). This method of assessment by banks has been practiced so far. 
The principles for extending credit provided by the Bank consist of:

1. Principle 5 C, namely:

a. Character (character)

Character is a belief that the character or character of the people who will be given a loan can truly be trusted. In this case, what the bank pays attention to is the attitude or behavior of the customer. The point of attention of the bank here is shown on the issue of honesty and good faith of customers. For this reason, the data submitted by the customer can be seen to what extent the truth is stated therein. Then from the individual customer as the head of the company is also a point of attention, whether the person concerned is a wasteful person, likes to evade responsibility and so on. All customer behavior in the past is used as input for the bank in considering the customer's willingness to pay off credit.

b. Capacity (ability)

Capacity, which is where the business to be financed by credit, in principle, the customer must be able to manage it well, because otherwise the business will not develop and will even become completely stuck. Which later the customer will have difficulty paying back the credit. Here the bank assesses the debtor's ability to manage the business that will be financed by credit. Banks need to know, whether the customer has sufficient knowledge in this field of business, whether the customer is experienced enough to manage his business.

c. Capital (capital)

Capital, which is used to determine the amount of capital a prospective debtor has sufficient enough to run his business. The bank functions only to provide additional capital. In general, the composition of capital provision for customer businesses is mostly financed by bank credit and a small part is financed by customers. To find out the extent to which customers are able to provide their own capital, it can be seen from the company's financial statements.

d. Collateral (guarantee)

Collateral, namely for credit repayment security, customers are required to provide assets to be used as collateral. Which can be used as collateral for both movable and immovable property. In addition to asking for a principal guarantee, the bank also asks for an additional guarantee. All collateral is worth at least the amount of credit given. In addition to collateral in the form of goods, the management of the credit recipient company is also required to be bound in a borough (person in charge).

e. Condition of Economy (state or economic conditions)

Namely, by looking at the credit which will also be assessed from the current economic conditions and the possibility for the future according to each sector, as well as due to the business prospects of the sector it is running on.

1. The 5 P principles, namely:

a. Party (borrower)

Namely classifying customers into certain classifications or certain groups based on their capital, loyalty and character.

b. Purpose (aim)

That is, the purpose of providing credit must be known by the bank. It must be seen whether the credit will be used for positive things that can actually increase the company's income. And must be monitored so that the credit is really intended for the purpose as promised in a credit agreement. 
c. Payment (payment)

That is a measure of how the customer returns the credit that has been taken or from any source of funds for credit repayment.

d. Profitability (yield)

Namely to analyze the customer's ability in relation to profit. For this reason, the bank must anticipate whether the profit to be obtained by the company is greater than the loan interest and whether the company's income can cover credit repayments.

e. Protection (protection)

That is, we need a credit protection by the debtor company. For this reason, it is important to pay attention to protection from group companies or personal guarantees of company owners.

The procedures for providing credit carried out by banks include:

1. Credit Application Stage

Applications are submitted by prospective debtors to the bank by submitting documents containing an official application letter, company establishment deed, business plan explanation, project feasibility study reports, company financial reports and other information such as NPWP (Taxpayer Identification Number), where the NPWP is continuously monitored by the Bank. Indonesia in every credit extension, then company domicile statement, permits that have been obtained, company accounts with several banks. In the application, prospective debtors / customers are asked to fill out a standard form that has been prepared by the bank concerned.

\section{Credit Analysis Stage}

Credit officers / analysts prepare a credit application preliminary examination report (LP3K). In this stage, the bank must directly examine the condition and physical condition of the prospective customer's business at its place of business and physically examine the customer's collateral that will be used as collateral.

These aspects of credit analysis include:

a. Juridical Aspects

Aimed at examining the legality provisions of the company that will obtain credit. What is analyzed is the business entity, permits that must be owned and permits.

b. Marketing Aspects

Used to examine the breadth and shape of the market, market share, level of business competition, a marketing plan projects that will be financed by the bank, an assessment of the policies and marketing strategies that will be pursued.

c. Management Aspects

This is to assess the management ability of project managers when the project is not yet operational and when the company is already running. Analyzed include organizational structure, job descriptions, systems and procedures, the character of the administrators and the implementation of management functions.

d. Technical Aspects (tailored to the customer's line of business)

Bank officers / credit analysts assess the project manager's ability to plan and implement project development. 
e. Financial aspect

To assess the ability and management skills of project managers when the project is not yet underway. The analysis includes an assessment of project financial data, an assessment of the financial data of companies that are already operating.

f. Socio-Economic Aspects

To assess the extent to which the added value of the project will be built and financed by the bank. The aspects assessed are subsidies, equity in business, use of local raw materials, tax revenues, and external impacts on the environment.

3. Approval Stage

In this stage, every credit approval must be decided by the credit committee by absolute decision.

4. Agreement Stage

The credit agreement is prepared by a Public Notary appointed by the bank or selected by the prospective debtor. The bank sends its legal experts to assist the credit officer in discussing the terms that will be contained in the credit agreement. The contents of the credit agreement include, among other things, the credit provider, the purpose of providing credit, the amount of the project cost, the amount of credit provided by the bank, the credit interest rate, other costs, the repayment period, the payment schedule, credit guarantees, conditions that must be met before disbursing, debtor's obligations as long as the credit has not been repaid, as well as the rights that the bank has as long as the credit has not been paid off.

In order to have legal force that binds the business, the credit agreement is signed by 3 (three) parties, namely the bank, debtor / customer and notary, then registered with the District Court in accordance with the domicile of the credit provider bank.

5. Credit Disbursement

The bank only approves credit disbursement by the debtor, if the conditions that must be met by the debtor have been implemented and approved by the management of the Bank. Credit disbursements that have been approved can be made by means and methods determined by the Bank, among others, by withdrawing a check or bilyet giro, with receipts, or by transferring the burden on the customer's loan account.

\section{How are the Bank's Policies in Rescue of Non-Performing Loans during the Covid-19 epidemic}

As for the efforts made by the bank, if the bank decides to take rescue action during the Covid-19 epidemic, of course it depends on the difficulties faced by the customer / debtor, then the options for action taken are as follows:

1. Rescheduling

This policy is related to the credit period so that the relief that can be given is:

a. Extend the credit period

b. Extending the period of installments, for example, the installments were originally set every 3 months, then to 6 months

2. Reconditioning

Namely changes in part or all of the credit terms which are not limited to changes in payment schedules, time periods and other terms as long as they do not involve changes in the maximum credit balance. In this case, the assistance provided is in the form of wishes or changes in credit terms, including: 
a. Interest capitalization

That is, the interest is made into principal debt so that the customer / debtor for a certain time does not need to pay interest, but later the principal debt can exceed the approved credit. This method is taken in the event that the customer's business prospects are good,

b. Postponement of interest payments until a certain time In this case, it means that only interest can be postponed, while the principal must still be paid as usual.

c. Conversion of short-term loans to long-term loans with lighter terms

3. Restructuring

If the customer / debtor's difficulties are caused by capital factors, then the solution is to review the situation and condition of capital, both capital in terms of funds for working capital needs and capital in the form of capital goods. Actions that can be taken in the context of restructuring are:

a. Give additional credit

If the customer lacks working capital, it is necessary to consider working capital investment.

b. Provide additional equity

If the additional credit is burdensome to the customer / debtor, in connection with the payment of interest, it is necessary to consider additional own capital in the form of 4. Combination additional / depositing money (fresh money).

Rescue action can also be a combination, for example reconditioning with restructuring, namely between changes in terms and credit terms and additional bank funds. In banking practice, credit repayments are often not always smooth, and sometimes bad credit occurs, especially during the Covid-19 epidemic. Bad credit is credit based on a reasonable assessment, it is known that a bank is very difficult to obtain repayment and it is difficult to save it because the recipient of the credit cannot return the credit due to the company's financial difficulties.

The company's financial difficulties are reflected in the condition of liquidity, profitability and / or solvency, the causes of which can be technical matters of the company as well as external factors / force majeure, including:

1. Internal Factors

a. Marketing Aspects

Is a cause of difficulty that is difficult to overcome. In this case, a product is said to be saturated in the market if the total of the same (similar) goods entering the market exceeds the demand for that good, so that many of the products are not sold. In addition, it is caused by internal factors such as quality, model and design which are low and disliked as well as lack of company service.

Then the bank actions that can be considered regarding the condition of the company are:

- If the goods cannot be sold due to general conditions, while the market is actually not saturated and business prospects are still there, then it is considered to conduct rescheduling.

- If marketing difficulties are due to quality, model, design, it is necessary to discuss with the customer / debtor the possibility of correcting these deficiencies, which can then be considered for rescheduling and if additional credit is given, if the research provides a positive picture with a good marketing record. 
b. Fund Aspect

Financial difficulties may be caused by a lack of funds for the scale of the company, both for working capital needs and for additional investment. This needs to be examined first, if the scale of the company is too small to be able to do business within reasonable limits, then additional investment is required. However, in the event that the company has not operated in accordance with its capacity (under capacity), what is needed is additional funds for working capital.

c. Technical Aspects

The things that cause the company's difficulties in technical terms can be internal conditions, for example, the design or model is no longer attractive and is caused by the aging of the engine. So in relation to internal conditions, it is necessary to study the prospects of marketing if these barriers or deficiencies can be overcome. It is necessary to know the strength of the competition, whether it can cover the market or if there is still market space left. If it is estimated that After these obstacles can be overcome and the market is available, the bank's actions will certainly help save the customer's / debtor's business, either by rescheduling credit or if necessary with additional working capital credit and investment credit (to replace old machines).

d. Management Aspects

Difficulties caused by the organization and management, among others, are in the form of less skilled and inexperienced personnel, bad faith such as manipulation and corruption as well as excess labor and so on. In dealing with these problems, the bank should be able to provide advice / mediate, how to overcome them, namely by means of corporate finance.

The impact of bank policies in saving non-performing loans during the Covid-19 pandemic, namely:

\section{Impact of Lending for Banks}

As previously known, Article 1 number (2) of the Banking Law No. 10 of 1998 has mentioned the definition of a bank. From this definition, it can be seen that the function of a bank is to collect funds and distribute them to the public in order to improve the standard of living of the people at large. In channeling funds or credit whose funds come from the public, banks need to handle them carefully. This is because these funds actually belong to the community. Therefore, banks always face considerable risks so that credits given to debtors by banks need to be secured, especially during the Covid-19 pandemic.

Without security, the bank will find it difficult to know every risk that comes, as a result of the debtor's under-performance. The risks faced by banks in this matter involve 2 (two) types, namely:

1. The risk of debtors' difficulties or liquidity;

2. Risk of congestion or debt repayment;

In order to reduce the risk referred to in essence, every credit extension must be based on the following considerations:

1. Each credit extension provided by the bank is only in the form of additional funds as a basis for completing the lack of capital from the debtor and is not intended to finance all capital needs.

2. Sources of funds for credit repayment are clear and truthful. 
An agreement is a legal act that can have legal consequences. An agreement made reciprocal will give rise to rights and obligations between the parties making the agreement. This also applies to bank credit agreements, where the parties to the credit agreement are between the bank (creditor) and the customer (debtor). So that if the debtor agrees, the credit agreement is signed by both parties so that from then on, rights and obligations will arise between them.

The positive impacts of providing credit for banks include:

1. Maintain the solvency of the bank's business, which aims to return public funds that have been used for the credit extension process

2. Banks get credit interest, which is the difference between credit interest and costs incurred by the bank and overhead costs in the framework of credit management.

3. The bank will get a provision from the credit it provides to customers / debtors

\section{Impact of Lending for Debtors}

With the provision of credit facilities provided by the bank to the customer / debtor, this means that the customer / debtor has the trust of the bank. So, if a debtor receives a loan from the bank, the debtor should use it properly. The positive impacts of providing credit for debtors include:

1. If the debtor uses the credit provided by the bank, the debtor will have the opportunity to improve his business

2. Debtors can expand and develop their business freely

3. Can increase the debtor's business income

In addition to the positive impacts that arise in the provision of credit, there are negative impacts that arise in the provision of credit to debtors, namely by being given credit if the debtor experiences a failure in his business so that the debtor is difficult to repay the credit, the bank will be able to take action on the debtor by taking rescue action. credit made by the bank against congestion committed by the debtor. In an effort to avoid bad credit, it is given to debtors or customers whose credit repayment ability is weakened at a predetermined time limit with a credit extension facility, which will also help the debtor or customer to continue his business. Of course, the provision of credit extension facilities that is carried out has an impact on the bank and the debtor or the customer itself.

The impacts include, among others:

1. Impact of credit extension for the bank

The bank gets credit interest income, which is the difference between the credit interest and the costs incurred by the bank and the overhead costs for processing the credit.

a. Maintain the solvency of the bank's business, which aims to return public funds that have been used for the credit extension process.

b. To prevent problem loans or bad credit by providing an extension of time for debtors to return their credit.

c. The bank will receive a provision from the credit it provides to debtors or customers

d. By giving credit extension, it is hoped that the circulation of money will return to normal, so that any existing problems can be resolved.

2. Impact of credit extension for the debtor

a. If the debtor uses this time extension facility, the debtor will have the opportunity to correct previous mistakes in his business activities.

b. Debtors can expand and develop their business freely 
c. The debtor can rearrange the framework and plan which is effective in demonstrating the extension of the credit period and the increase in the amount of credit, of course, under the supervision of the bank.

\section{Conclusion}

a. The existence of a credit relationship begins with an agreement between the borrower (debtor) and the lender (creditor / bank) as outlined in the form of an agreement. Lending in general can be given to anyone who has the ability to do so, namely by means of a debt-receivable agreement. If the agreement has been agreed, there will be an obligation on the creditor, namely, to deliver the funds or money that has been agreed upon to the debtor with the right to receive the money back from the debtor at a predetermined time accompanied by the interest agreed by the parties at the time of the credit agreement. agreed and signed by both parties.

b. Fulfillment of debtor obligations in the loan agreement during the Covid-19 pandemic, in general, there are several debtors who do not meet the achievements as in the credit agreement between the bank and the debtor.

c. The policy of restructuring credit / financing and / or providing additional credit / capital financing for people's credit banks during the Covid 19 epidemic is a rescue action, while the options for action taken are Rescheduling, Reconditioning, Restructuring, Combination of reconditioning with restructuring, namely: changes in terms and credit terms with additional bank funds.

\section{Suggestion}

Based on the above conclusions, the author will try to provide the following suggestions:

a. In granting credit by the bank, it is better to examine in detail the feasibility of the business being carried out by the debtor in advance. We recommend that the business run by the debtor is a business that can improve the country's economy.

b. To avoid one of the obstacles in the credit sector, the bank needs to provide credit to debtors who need it, such as to develop their business. And the principles of giving must be implemented as best as possible to avoid bank bad credit.

c. If the provision of credit for the debtor's business causes more negative impacts on the bank, the bank should first take action to rescue bank credit. In rescuing the debtor's business, he must pay attention to this marketing aspect in a situation where credit is still possible.

\section{References}

[1] Abdul Kadir Muhammad, Engagement Law, Alumni, Bandung, 2001

[2] Abdul Kadir Muhammad, Legal Aspect of Financial and Financing Institutions, Citra Aditya Bhakti, Bandung, 2000.

[3] Achmad Sanuri, Introduction to Law and Introduction to Indonesian Law, Tarsito, Bandung, 1994.

[4] Bambang Sunggono, Research Methodology, Radja Grafindo Persada, Jakarta, 1997 
[5] Djanius Djamin and Syamsul Arifin, Basic Materials of Civil Law, Perbanas Academy of Finance and Banking, Medan, 2001.

[6] Ediwarman, Monograph Legal Research Methods Transitional Edition I, Medan, ttp, 2008

[7] Hadari Nawawi, Applied Research, Gajah Mada University Press, Yogyakarta, 2006

[8] Hardijan Rusli, Indonesian Agreement Law and Common Law, Pustaka Sinar Harapan, Jakarta, 1998

[9] Hasanuddin Rahman, Legal Aspects of Providing Banking Credit in Indonesia, Citra Aditya Bakti, Bandung, 1998.

[10] Jhon M Echols and Hasan Sadily, Indonesian English Dictionary, Gramedia, Jakarta, 1997.

[11] Joni Emirzon, Indonesian Business Law, Directorate General of Higher Education, Ministry of National Education, Jakarta, 2002.

[12] J Satrio, Agreement Law, Citra Aditya Bakti, Bandung, 1993.

[13] Juajir Sumardi, Agreement as the Basis for Franchise Business Relations, PPSUI, Jakarta, 2003.

[14] Kartini Muljadi and Gunawan Widjaya, Series of Bond Law (Bonds Born From Agreements), Raja Grafindo Perkasa, Jakarta, 2003.

[15] Muchdarsyah Sinungan, Basics and Techniques of Credit Management, Bumi Aksara, Jakarta, 1993

[16] Muhamad Djumhana, Banking Law in Indonesia, Citra Aditya Bhakti, Bandung, 1996

[17] Munir Fuady, Contract Law, Citra Aditya Bakti, Bandung, 2001.

[18] M Yahya Harahap, Aspects of Agreement Law, Alumni, Bandung, 1996.

[19] Sudikno Mertokusumo, Invention of the Law An Introduction, Liberty, Yogyakarta, 2001

[20] Supraba Sekarwati, Contract Design, Alumni, Bandung, 2001

[21] Thomas Suyatno, Fundamentals of Credit, Gramedia Pustaka Utama, Jakarta, 1991.

[22] Tri Widyono, Legal Aspects of Operational Banking Product Transactions in Indonesia, Ghalamania Indonesia, Bogor, 2006.

[23] Winarni Surakhmad, Basic and Engineering Research, Transito, Bandung, 1997

[24] Law Number 10 of 1998 concerning Banking 